\author{
Vasytynska L. \\ Ph.D., Associate Professor \\ Department of Finance \\ Odessa National Economic University \\ Preobrazhenska str., 8 , Odessa, Ukraine, 65082 \\ E-mail: tereza.vaslud@gmail.com \\ Nemchenko $\mathrm{H}$. \\ Assistant \\ Department of Management of Business \\ Odessa National Academy of Food Technologies \\ Kanatna str., 112, Odesa, Ukraine, 65039 \\ E-mail: annem2956@gmail.com
}

\title{
FINANCIAL INSTRUMENTS FOR PROVISION OF SUSTAINABLE ECONOMIC GROWTH OF TERRITORIAL DEVELOPMENTS
}

The problems of formation of revenues of local budgets are investigated in the article. It has been established that significant centralization has affected the reduction of financial independence of local selfgovernment bodies. Changes in the management of local budgets caused by the introduction of a decentralized model encourage local self-government bodies to attract additional financial resources and form a certain economic potential. The feasibility of introducing a public-private partnership through the application of different methods and tools based on the form of interaction of project participants is substantiated. Such cooperation requires the organization of complex, mixed private-public structures that can provide largescale infrastructure projects with resources. The advantages of project financing of economic development of territories in the framework of public-private partnership (PPP) are revealed.

In order to ensure the financial attractiveness of projects implemented on the basis of public private partnership and aimed at ensuring the sustainable economic development of regions, it is recommended to use organizational models such as DBFO (Design, Build, Finance, Operate) and DBO (Design, Build, Operate).

Key words: revenues of local budgets, local self-government bodies, public-private partnership, financial decentralization, financial resources.

This work is licensed under a Creative Commons Attribution 4.0 International License http://creativecommons.org/licenses/by/4.0/

Statement of the problem and its connection with important scientific and practical tasks. The anticrisis model of the modernization of Ukrainian economy implies a transfer from strategy of adaptation and survival to the strategy of sustainable growth, in which there is selection tools of local governance. The introduction of a decentralized model into the financial resources management system of local self-government has radically changed approaches to the formation and use of local budgets, increasing the influence of local self-government on creating a strong economic potential of the regions. The multidimensional tasks to be performed by the administrators of budgetary funds against the background of limited sources of income will raise the issue of the implementation of effective tools in the system of management of financial resources of local government.

The analysis of the latest publications on the problem. The issues of finding ways to solve problems concerning the formation and use of financial resources of local self-government, deepening of theoretical principles and development of the methodology of functioning of the system of local finances are dealt with in the works of such scholars as I. Lunina, S. Slukhai, S. Yurii, N. Savchuk, G. Voznyak, O. M. Kruk, O.

Vasilik, V. Kravchenko and many others.

Forming of the aims of the research. The purpose of the article is to study the tools for ensuring the financial independence of local self-government and to identify the benefits of project financing of the economic development of territorial entities within the framework of the PPP.

Giving an account of the main results and their substantiation. The importance of solving the problems of reaching a consensus on the positions of the three parties: the state, regions and municipalities and the identification of the reasons for the inactivity of existing levers on increasing financial capacity form the field of the research.

The problem that is taking place in implementing the reforms of local self-government in the modern period is the result of retrospective budgetary regulation, which was based on the primacy of centralization. The 
dependence of local budgets on the state over a long period has deepened the contradiction between the interests of the authorities and the territorial communities, reducing the interest of the latter in increasing the economic potential of the territory concerned.

This problem is especially acute in municipalities where there are no large companies which are able to meet their own investment needs and invest in the devel- opment of regional and local infrastructure. Therefore, activation of the processes aimed at increasing the own income of territorial communities at the present stage of economic development is a priority task.

The structure of local budget revenues in Ukraine (Table 1) has been analyzed for the study of the issues of ensuring the financial independence of local budgets.

Table 1

Structure of revenues of local budgets in 2012-2016,\%*

\begin{tabular}{|l|c|c|c|c|c|}
\hline \multicolumn{1}{|c|}{ Indexes } & 2012 & 2013 & 2014 & 2015 & 2016 \\
\hline $\begin{array}{l}\text { The share of official transfers in local } \\
\text { budget revenues }\end{array}$ & 55.3 & 52.4 & 56.4 & 59.1 & 53.4 \\
\hline $\begin{array}{l}\text { The share of tax revenues in local budget } \\
\text { revenues }\end{array}$ & 38.1 & 41.3 & 37.7 & 33.4 & 40.1 \\
\hline Non-tax revenues & 6.6 & 6.3 & 5.9 & 7.5 & 6.5 \\
\hline Total & 100 & 100 & 100 & 100 & 100 \\
\hline $\begin{array}{l}\text { The share of tax revenues in missed budget } \\
\text { revenues (excluding official transfers) }\end{array}$ & 85.1 & 86.7 & 86.4 & 81.6 & 86.1 \\
\hline taxes on income, including: & 61.0 & 62.1 & 62.1 & 49. & 49.7 \\
\hline tax and personal income tax & 60.6 & 61.4 & 61.9 & 45.6 & 46.3 \\
\hline property taxes & 0.7 & 0.5 & 0.4 & 0.0 & 0.0 \\
\hline rent & 15.1 & 14.2 & 14.4 & 1.8 & 1.5 \\
\hline internal taxes on goods and services & 1.2 & 1.3 & 0.2 & 6.4 & 6.8 \\
\hline local taxes & 5.4 & 7.0 & 8.0 & 22.4 & 24.8 \\
\hline other taxes and fees & 1.7 & 1.6 & 1.3 & 1.8 & 3.3 \\
\hline
\end{tabular}

* Compiled by the authors according to [1]

As shown in Table 1, PIT remains the main budget forming tax. The change in the share of the income of the PIT is due to changes in the distribution of the above mentioned tax between the types of budgets. The demarcation rules that were adopted in 2015 assume that $25 \%$ of income of the PIT is directed to the State Budget, $15 \%$ - to the regional budgets, $60 \%$ - to the budgets of local self-government [2] .However, this tax is nationwide, and therefore local authorities cannot administer its administration and have no opportunity to promptly influence the processes of its mobilization to the corresponding budgets.

The main reason for the change in the share of local taxes and fees is to expand the tax base of the property tax, which includes land payment and transport tax [3]. As the world experience shows, a real estate tax is considered a very effective tool in strengthening its own revenue base of local self-government. According to the World Bank's monitoring, the tax is taxed at $40-80 \%$ of local government budget revenues in the economically developed countries. In particular, in the Netherlands, its share in the revenues of local budgets is $95 \%$, in Canada $81 \%$, in France - 52\%, in the USA, depending on the legislation of the state from 10 to $70 \%$ [4-5]. However, in Ukrainian realities, the imperfection of tax legislation regarding the definition of the tax base for real estate tax reduces the ability of local self-government bodies to create a sufficient income base [6]. In particular, the statutory norms do not provide for the levying of a tax on immovable property from areas of production or commercial use.
In the context of this conceptualization and substantiation of the goals of the activities of local selfgovernment bodies is a prerequisite for attracting and retaining financial resources in the territory of the municipal entity. Such format will allow economic entities to weigh the risks of using financial and credit instruments in the domestic financial market for the purpose of targeted financing of relevant local (regional) projects and programs.

The experience of developed market economies shows that the most important component of strengthening the economic potential of territories is the introduction of market mechanisms and the involvement of private business in the implementation of projects of local importance. Possibilities of partnership of local governments and business as well as attract of investments to solve Issues of economic development of subdivisions are limited for reasons of the absence of the necessary institutional preconditions for the organization of the interaction of municipalities and private business within the framework of the PPP and the undeveloped regional financial markets .

It is known that the priorities of regional development are focused on the global goal of improving the well-being and living standards of the population. Therefore, as a rule, the implementation of regional projects is aimed at the production of a specific product public goods, which are low in the commercial component. This reduces the motivation of a private partner. However, the foreign experience of implementing PPP projects in the developed countries 
is quite convincing. According to expert opinions, 75$80 \%$ of such projects are implemented within the framework of cooperation between municipal authorities and the business sector. It makes sense to draw attention to the fact that the delegation of authority to produce and provide public goods to a private partner is carried out in all spheres of socio-cultural development [7-8].

PPP projects can be implemented in any form of interaction, in particular by leasing, budget financing and lending, forfeiting in compatible business, concession agreements, distribution agreements of the derived products and others. As can be seen, the possibility of using a variety of financial instruments with appropriate institutionalization will enable not only to attract additional financial resources but also to keep them in territorial formations.

In a market economy, the key to the implementation of any projects, including within the framework of the PP, is the sufficiency of financial support. In addition, the benefits derived from the implementation of such projects should at least fully cover the costs of their implementation. Formation of an effective financial model of the PPP can be achieved through the application of different methods and tools, taking into account the form of interaction of project participants who are responsible for particular stages of the creation process of new consumer value. Such co-operation requires the organization of complex, mixed private-public structures that can provide large-scale infrastructure projects with resources.

The advantages of project financing of economic development of territories within the framework of the PPP are that, firstly, the consistency of the objectives of economic entities and their compliance with the priorities of the strategy of socio-economic development of the territory is achieved. Secondly, the risks of ineffective use of funds are reduced due to the increased control over the movement of the financial flows by both partners. Thirdly, the stability of the financial system of the region is ensured as a result of an increase in incoming financial flows. Fourthly, the investment attractiveness of a particular area, which is generated by private investors, is increasing. Fifth, access is expanding to alternative sources of funding, including language and where the financial support of international economic organizations and financial institutions. Sixth, the investment risks in our country are reduced as result of their partners. Seventh there is a saving expenditure on maintenance and operation of facilities due to funds of a business partner. The freed financial resources can be diverted to other goals of economic development. Eighth, the effectiveness of project management is increased through the transfer of powers to the business partner to perform financial and economic functions, which for the latter are more peculiar than for the authorities.

The IFR financial framework usually involves a certain sequence of actions that reflect the functional side of the financial mechanism of projects based on publicprivate partnerships. The main stages of this process are:

- development of a project, within which it is planned to realize the interests of its participants through the creation and operation of investment objects;

- financing of investments from different sources and realization of investment phase of the project;

- exploitation of the objects created within the framework of the project, by concluding long-term contracts, and obtaining benefits (including financial) by all project participants according to their purposes ;

- transition of the investment object after the termination of the contract into a private or municipal property.

In world practice, different organizational models are used that provide the necessary financial attractiveness of PPP projects and take advantage of this form of interaction. Such models as DBFO (Design, Build, Finance, Operate -Design, Construction, Financing, Operation / Management) and DBO (Design, Build, Operate - design, construction, operation / management) can be considered as sufficiently promising for application [9-10]. These models are prestigious in their organization. Thus, the first involves the delegation of a public partner of all four functions to a private partner. The essence of the other is that the public partner finances the project throughout his life cycle, and then passes it for business to a private partner, provided that the rent is made by the latter. This model is used, as a rule, when implementing sufficiently large infrastructure projects.

Conclusions and prospects of the further investigations. The Research conducted makes it possible to conclude that the existing tax mechanism and the corresponding toolkit used at the local level of the budgetary system in Ukraine do not ensure the real self-sufficiency of territorial entities. Therefore, there is a need to attract additional financial resources for the formation of strong economic potential of the regions. Application of publicprivate partnership is recognized as one of the most effective forms of implementation of economic development projects at the local level. This leads to the continuation of research in the direction of solving issues regarding the development of practical models of financing the projects of economic development of territorial entities on the basis of public-private partnership.

\section{References}

1. Derzhavna kaznacheiska sluzhby Ukrainy. Veb-portal. (2018). Retrieved from http://www.treasury.gov.ua.

2. Biudzhetnyi kodeks Ukrainy vid 08.07.2010 № 2456-VI : Za stanom na 01.01.2018 r. (2018). Retrieved from http://zakon2.rada.gov.ua/laws/show/2456-17/ed20170101//

3. Podatkovyi kodeks Ukrainy vid 02.12.2010 № 2755-VI : Za stanom na 07.12.2017 r. (2017). Retrieved from http://zakon3.rada.gov.ua/laws/show/2755-17. 
4. Flissak, N. (2007). Svitovyi dosvid u spravlianni podatku na nerukhome maino. Konsultant, (34), 23-30.

5. Stipakhno, V. I. (2012). Zarubizhnyi dosvid stiahnennia podatku na nerukhomist. Formuvannia Rynkovykh Vidnosyn v Ukraini, (9), 18-25.

6. Vasiutynska, L. A., \& Slatvinska, M. O. (2016). Podatkovi dominanty zbilshennia dokhodnoi bazy mistsevykh biudzhetiv v. Ukraini. Ekonomika. Finansy. Pravo., (2/1), 33-37.

7. Gerrard, M. B. (2010). What are public-private partnerships, and how do they differ from privatizations? Finance \& Development, 38(3), 26-31.

8. Polackova, B. H., Budina, N., \& Irwin, T. Managing Fiscal Risks in PPPs. In Current Issues in Fiscal Reform in Central Europe and the Baltic States 2005. Washington: World Bank.

9. Akintoye, A., \& Beck, M. (Eds.). (2009). Policy finance \& management for public-private partnership. Oxford: Wiley-Blackwell.

10. Lenk, T. (Ed.). (2011). Public-private partnership: an appropriate institutional arrangement for public services? Baden-Baden: Nomos-Verl.-Ges.

Received 24 February 2018

Approved 10 March 2018

Available in Internet 7.07.2018

\author{
Васютинская Л.А. \\ кандидат экономических наук, доцент \\ кафедра финансов \\ Одесский национальный экономический университет \\ ул. Преображенская, 8, г. Одесса, Украина, 65082 \\ E-mail: tereza.vaslud@gmail.com \\ Немченко А.B. \\ ассистент \\ кафедра управления бизнесом \\ Одесская национальная академия пищевых технологий \\ ул. Канатная, 112, г. Одесса, Украина, 65039 \\ E-mail: annem2956@gmail.com
}

\title{
ФИНАНСОВЫЕ ИНСТРУМЕНТЫ ОБЕСПЕЧЕНИЯ УСТОЙЧИВОГО ЭКОНОМИЧЕСКОГО РОСТА ТЕРРИТОРИАЛЬНЫХ ОБРАЗОВАНИЙ
}

\footnotetext{
Внедрение децентрализованной модели в систему управления финансовыми ресурсами органов местного самоуправления в корне изменило подходы к формированию и использованию местных бюджетов, усиливая влияние местного самоуправления на создание прочного экономического потенциала регионов.

Значимость решения проблем по достижению консенсуса позиций трех сторон: государства, регионов и муниципалитетов и выявления причин недейственности существующих рычагов по наращиванию финансовой состоятельности формируют поле исследования.

Целью статьи является исследование инструментария по обеспечению финансовой независимости местного самоуправления и определение преимуществ проектного финансирования экономического развития территориальных образований в рамках частно-публичного партнерства.

В статье исследованы проблематику формирования доходов местных бюджетов. Установлено, что значительная централизация повлияла на снижение финансовой независимости органов местного самоуправления. Однако изменения в управлении местными бюджетами, вызванных внедрением децентрализованной модели, побуждают органы местного самоуправления привлекать дополнительные финансовые ресурсов и формировать определенный экономический потенциал. Обоснована целесообразность введения публично-частного партнерства путем применения различных методов и инструментов, учитывая форму взаимодействия участников проекта. Такая кооперация требует организации сложных, смешанных частно-публичных структур, которые способны обеспечивать ресурсами масштабные инфраструктурные проекты. Раскрыто преимущества проектного фринансирования экономического развития территорий в рамках через механизм государственно-частного партнерства. Для обеспечения фринансовой привлекательности проектов, реализуемых на основе публичного частного партнерства и направленные на обеспечение устойчивого экономического развития регионов, рекомендовано применение таких организационных моделей, как DBFO (проектиро-
} 
вание, строительство, финансирование, эксплуатация / управление) и DBO (проектирование, строительство, эксплуатация / управление).

Ключевые слова: доходы местных бюджетов, органы местного самоуправления, публичночастное партнерство, финансовая децентрализация, финансовые ресурсы.

\author{
Васютинська Л.А. \\ кандидат економічних наук, доцент \\ кафедра фінансів \\ Одеський національний економічний університет \\ вул. Преображенська, 8, м. Одеса, Україна, 65082 \\ E-mail: tereza.vaslud@gmail.com \\ Немченко Г.В. \\ асистент \\ кафедра управління бізнесом \\ Одеська національна академія харчових технологій \\ вул. Канатна, 112, м. Одеса, Україна, 65039 \\ E-mail: annem2956@gmail.com
}

\title{
ФІНАНСОВІ ІНСТРУМЕНТИ ЗАБЕЗПЕЧЕННЯ СТАЛОГО ЕКОНОМІЧНОГО ЗРОСТАННЯ ТЕРИТОРІАЛЬНИХ УТВОРЕНЬ
}

Впровадження децентралізованої моделі в систему управління фінансовими ресурсами органів місцевого самоврядування докорінно змінило підходи до фрормування і використання місцевих бюджетів, посилюючи вплив місцевого самоврядування на створення міцного економічного потенціалу регіонів.

Значимість вирішення проблем щодо досягнення консенсусу позицій трьох сторін: держави, регіонів і муніципалітетів та виявлення причин недієвості існуючих важелів щодо нарощення фінансової спроможності формують поле дослідження.

Метою статті $€$ дослідження інструментарію щодо забезпечення фрінансової незалежності місцевого самоврядування та визначення переваг проектного фінансування економічного розвитку територіальних утворень у рамках приватно-публічного партнерства.

У статті досліджено проблематику формування доходів місцевих бюджетів. Встановлено, що значна централізація вплинула на зниження фрінансової незалежності органів місцевого самоврядування. Проте зміни в управлінні місцевими бюджетами, які спричинені впровадженням децентралізованої моделі, спонукають органи місцевого самоврядування залучати додаткові фрінансові ресурсів та формувати певний економічний потенціал. Обґрунтовано доцільність запровадження публічноприватного партнерства шляхом застосування різних методів та інструментів з огляду на форму взаємодії учасників проекту. Така кооперація вимагає організації складних, змішаних приватно-публічних структур, які здатні забезпечувати ресурсами масштабні інфраструктурні проекти. Розкрито переваги проектного фінансування економічного розвитку територій у рамках через механізм публічноприватного партнерства. Для забезпечення фрінансової привабливості проектів, що реалізуються на засадах публічного приватного партнерства і спрямовані на забезпечення сталого економічного розвитку регіонів рекомендовано застосовування таких організаційних моделей, як DBFO (проектування, будівництво, фінансування, експлуатація / управління) та DBO (проектування, будівництво, експлуатація / управління).

Ключові слова: доходи місцевих бюджетів, органи місцевого самоврядування, публічноприватне партнерство, фрінансова децентралізація, фрінансові ресурси.

\section{Література}

1. Державна казначейська служби України. Веб-портал. [Електронний ресурс]. - Режим доступу: http://www.treasury.gov.ua.

2. Бюджетний кодекс України від 08.07.2010 № 2456-VI : за станом на 01.01.2018 р. - [Електронний ресурс]. - Режим доступу: http://zakon2.rada.gov.ua/laws/show/2456-17/ed20170101//.

3. Податковий кодекс України від 02.12.2010 № 2755-VI : за станом на 07.12.2017 р. - [Електронний ресурс]. - Режим доступу: http://zakon3.rada.gov.ua/laws/show/2755-17. 
4. Фліссак Н. Світовий досвід у справлянні податку на нерухоме майно / Н. Фліссак // Консультант. 2007. - № 34. - C. 23-30.

5. Стіпахно В.I. Зарубіжний досвід стягнення податку на нерухомість / В.І. Стіпахно // Формування ринкових відносин в Україні. № 9. - 2012. - С. 18-25.

6. Васютинська Л.А. Податкові домінанти збільшення доходної бази місцевих бюджетів в. Україні. / Л.А. Васютинська, М.О. Слатвінська // Економіка. Фінанси. Право. - 2016. - № 2/1. - С.33-37.

7. Gerrard M. B. What are public-private partnerships, and how do they differ from privatizations? / M. B. Gerrard // Finance \& Development. - 2010. - Vol. 38, № 3. - P. 26-31.

8. Polackova Brixi H., Budina N., Irwin T. Managing Fiscal Risks in PPPs / Current Issues in Fiscal Reform in Central Europe and the Baltic States 2005. - Washington: World Bank. - 30 c.

9. Policy finance \& management for public-private partnership / [edited by A. Akintoye, M. Beck]. - Oxford : Wiley-Blackwell, 2009.

10. Public-private partnership: an appropriate institutional arrangement for public services? / [T. Lenk (ed.)]. - Baden-Baden : Nomos-Verl.-Ges., 2011.

Стаття надійшла 24.02.2018 Стаття прийнята до друку 10.03.2018 Доступно в мережі Internet 7.07.2018 